\title{
Genetic Diversity among Varicella-Zoster Virus Vaccine Strains
}

\author{
Se Hwan Kang, Seok Cheon Kim, Jeong Yeol Kim, Chan Hee Lee* \\ Department of Microbiology, Chungbuk National University, Cheongju 28644, Republic of Korea
}

\author{
Corresponding \\ Chan Hee Lee, Ph. D. \\ 1 Chungdae-Ro, Seowon-Gu, Cheongju, \\ Chungbuk 28644, Department of \\ Microbiology, Chungbuk National \\ University, Republic of Korea \\ Phone : +82-43-261-2304 \\ Fax : +82-43-264-9600 \\ E-mail : chlee@chungbuk.ac.kr
}

Received : June 11, 2020

Revised : June 23, 2020

Accepted : June 23, 2020

No potential conflict of interest relevant to this article was reported.

Copyright (C) 2020 Journal of Bacteriology and Virology

(C) This is an Open Access article distributed under the terms of the Creative Commons Attribution Non-Commercial

License

(http://creativecommons.org/

license/by-nc/3.0/).
Varicella-zoster virus (VZV) is a causative agent for chickenpox in primary infection and shingles after reactivation from latency. Both varicella and zoster can be prevented by live attenuated vaccines, but the molecular mechanism of attenuation is not clearly understood. In this study, the genome sequences of three varicella vaccine strains were analyzed for the genetic diversity including single nucleotide polymorphism (SNP) and genetic polymorphism. A total of 38 SNPs were identified including 29 substitutions and 9 insertion/deletions. The number of genetically polymorphic sites (GPS) was highest in Varivax and lowest in Varilrix. GPS in the $\mathrm{R}$ region including $\mathrm{R} 1, \mathrm{R} 2$, and $\mathrm{R} 3$ appeared to be responsible for the genetic polymorphisms in the open reading frame (ORF) 11, 14 , and 22 in all three vaccine strains. A relatively large number of GPS were observed in ORF31, 55, and 62, which are known to be essential for virus replication, suggesting that the attenuation of the vaccine strains may be attributed by the diversity of these genes.

Key Words: Varicella-zoster virus, Vaccine, Whole genome sequence, Genetic diversity

\section{INTRODUCTION}

수두-대상포진 바이러스(varicella zoster virus, VZV)는 수두(varicella, chicken pox)와 대상포진(herpes zoster, shingles)을 발병시킨다. 수두는 VZV 바이러스가 처음 감염했을 때 나타나는 질병으로 주로 소아에게 발생하며 미열, 두통, 피부 발진 등의 증상이 유발된 다 (1). 초기감염 후 바이러스는 배근 신경절로 이동하여 휴지기에 들어가는 잠복감염을 하 게 되며, 사람의 면역력이 저하되었을 때 잠복기의 바이러스가 다시 활성화되면 대상포진 이 발생하며 국부적인 통증과 수포성 발진을 일으킨다 $(2,3)$. VZV는 유일하게 사람만을 숙주로 삼아 숙주 특이성이 높고, 자연 상태에서는 사람 이외의 동물에게 병원성이 나타나 지 않는 것으로 알려져 있다 (4).

수두와 대상포진은 모두 약독화 생백신으로 예방할 수 있다. 1974년 일본에서 수두에 걸 린 Oka라는 3세 남아로부터 분리한 야생주인 pOka주를 계대배양으로 약독화하여 vOka 백신주가 개발되었다. 약독화 방법에는 이종세포인 기니피그 배아 섬유아세포에서의 계대 배양을 포함하였다 $(5,6)$. 이렇게 개발된 수두백신은 1988년부터 일본에서 상품화되었 다. 이후 미국에서 $\mathrm{vOka}$ 를 기반으로 하여 Merck사의 Varivax와 GSK사의 Varilrix가 개발 되었다 (7). 국내에서는 한국인 수두환자에서 분리한 바이러스를 약독화한 바이러스인 MAV/06주를 사용하여 Suduvax가 개발되었다 (8). Suduvax는 한국에서는 1994년부터 상용화되었고 국제적으로는 1998년부터 판매되었다.

VZV 약독화 백신의 작용 기전은 아직까지 명확하게 규명되어 있지 않다. 그러나 pOka주 의 염기서열 비교 $(9,10)$, 그리고 여러 백신주와 임상주들간의 게놈 서열비교(11)에 의해 
백신주에만 나타나는 특이 염기서열이 제시된 바 있다. 한편 일부의 바이러스에 변이가 축적되면 바이러스 집단에서 게놈의 변이를 유도 하고 그 결과 다양한 변종이 발생하게 되는데 이렇게 발생한 바이러스 개체군은 약독화와 같은 생물학적 특성을 결정할 수 있다 (12). 변 종 바이러스 개체군을 quasispecies라 하며 이는 바이러스의 유전적 다형성을 가장 잘 표현할 수 있는 단어이다 (13). 유전적 다형성에 의해 신경독성이 변할 수 있다는 것이 Mumps 백신에서도 보고되었다 (14).

본 연구에서는 Next generation sequencing (NGS) 기법을 사용하여 대표적인 수두 백신주(Suduvax, Varilrix, Varivax)의 SNP 분석 과 유전적 다형성 분석을 통해 약독화에 따른 각 백신주가 어떠한 유전학적 특징과 다양성을 가지고 있는지 분석하고자 하였다.

재료 및 방법

DNA 추출 및 $q-P C R$

백신주는 (주GC녹십자(Yongin, Gyeonggi, Korea)로부터 제공 받은 Suduvax (Lot No. MG1111-FF-012), Varilrix (Lot No. A70CC807B), Varivax (Lot. No M015462) 제품을 사용하였다. 분말 상태의 제품 1개당 PBS $0.5 \mathrm{~m} \ell$ 에 녹여 $1.5 \mathrm{ml}$ E-tube에 담아 준비하였다.

준비한 백신주 시료를 Exgene ${ }^{\mathrm{TM}}$ Cell SV mini kit (GeneAll Biotechnology, Seoul, Korea)를 이용하여 DNA를 추출하였다. 바이러스 성 DNA와 세포성 DNA의 양을 확인하기 위해 IQ SYBR Green SuperMix (BIO-RAD, Hercules, CA, USA)로 q-PCR을 진행하였다. 기 존에 알려진 참고문헌을 활용하여 세포성 DNA, VZV DNA를 각각 검출할 수 있는 2쌍의 primer를 이용하였다. 세포성 DNA양을 확인하 기 위해 glyceraldehyde-3-phosphate dehydrogenase (GAPDH) 부위를 증폭하는 primer를 사용하였고, VZV의 바이러스성 DNA양 을 확인하기 위해 ORF4 부위를 증폭하는 primer를 사용하였다 $(15,16)$. IQ SYBER Green SuperMix $10 \mu \ell$, DNA template $1 \mu \ell, 10$ pmol 농도의 forward primer (5'-ATCTCCGTACAACATCAACT-3')와 reverse primer (5'-CGATTTTCCAAGAGAGACGC-3') 각각 $0.6 \mu \ell$ 를 혼합하고 전체 혼합액의 양이 $20 \mu \ell$ 가 되도록 증류수를 넣어주었다. q-PCR은 initial denaturation $94^{\circ} \mathrm{C} 240$ 초 1 회 이후 denaturation $94^{\circ} \mathrm{C}$ 30초, annealing $48.9^{\circ} \mathrm{C} 30$ 초, extension $72^{\circ} \mathrm{C} 30$ 초 조건으로 45 회 반복하였다. 바이러스 DNA에 대하여 시행한 q-PCR의 Ct값를 이용해 바이러스 시료 각각의 DNA양을 정량하였다. 이를 토대로 바이러스 간의 DNA 양의 균등화를 통해 객관적인 비 교를 할 수 있도록 하였다.

\section{차세대 시퀀싱(Next generation sequencing: NGS)}

추출한 바이러스 DNA의 전체 게놈 시퀀싱은 Illumina사(San Diego, CA, USA)의 Hi-Seq 2500 rapid 시스템으로 실시하였고, 이 과정 은 (체테라젠이텍스(Suwon, Gyeonggi, Korea)에 의뢰하였다. DNA library 제작은 Illumina TruSeq DNA Sample Preparation kit v2 를 사용하였고, 제작된 library를 Hi-Seq 방식으로 시퀀싱하고 Illumina version 1.8을 사용하여 품질이 낮게 나온 read들을 제거하였다. 일정한 품질이 보장된 read들은 CLC Geneomics Workbench version 5.0 프로그램에 기본 파라미터 값을 적용하고 NCBI에 등록되어 있는 MAV/06 (JF306641), Varilrix (DQ008354), Varivax (DQ008355)주를 참고주로 하여 mapping assemble을 수행하였다. Mapping assemble의 결과 하나의 완성된 염기서열을 얻을 수 있었고 이를 NCBI GenBank에 등록하였다: Suduvax MT370825, Varilrix MT370826, Varivax MT370827.

\section{ORF 위치 정보}

게놈 전체의 염기서열을 얻은 백신주의 ORF는 각각 mapping에 사용한 서열을 기준으로 local blast를 진행하여 특정하였다. 그리고 CLC Sequence Viewer (ver.6.1, http://www.clcbio.com/index.php)의 ORF 확인 기능, NCBI에서 제공하는 ORF Finder 프로그램 과 Bioedit Sequence Alignment Editor (version 7.0.9.0, http://www.mbio.ncsu.edu/BioEdit/bioedit.html)를 이용하여 온전한 형태의 시작코돈과 종결코돈을 갖는 ORF인지 확인하였다.

\section{단일 염기 다형성 분석}

DNA 대표 염기서열에서 차이를 보이는 유전적 변화 또는 변이를 단일 염기 다형성(Single nucleotide polymorphism; SNP) 이라고 한 
다. 백신주의 NGS 분석을 통해 얻어진 대표염기서열(Consensus sequence)을 Bioedit으로 읽고, ClustalW2 (version 2.1)를 이용하 여 VZV의 참고주인 Dumas주의 게놈 염기 서열(NC001348)과 함께 정렬시켜 동일한 위치에서의 SNP 분석을 진행하였다.

\section{유전적 다형성 분석}

유전적 다형성은 개체군에 존재하는 임의의 동일한 위치 염기에서 2 개 이상의 염기를 함께 가지고 있는 것을 말한다. 백신주의 NGS 분석으로 얻은 전체 염기서열 결과 파일(Counts 파일)로 염기서열의 각 위치별 A, C, G, T의 mapping 개수에 관한 정보를 얻을 수 있었다. Counts file에서 각 위치별로 mapping된 염기들 중, 가장 많은 비율을 차지하는 염기가 다수 염기(Major base)가 되고, 해 당위치에서의 대표염기서열로 결정된다. 두 번째로 많은 비율을 차지하는 염기가 소수 염기(Minor base)로 결정된다. 백신주의 NGS 분석으로 얻은 Counts file을 이용하여 다수 염기와 소수 염기의 백분율을 구하였다. 이 때, 특정 위치에서 mapping 된 read의 개수가 35 개 이상인 경우에만 유전적 다형성 분석에 유의하다고 판단하였다. 그리고 소수 염기의 비율이 $5 \%$ 이상인 위치를 유전적 다형성 부위 (Genetically polymorphic site; GPS)라고 명명하고, 이 위치들만 유전적 다형성 분석에 사용하였다 (17). Counts file 은 우리 실험실에서 개발한 GPA (Genetic Polymorphism Analyzer) 프로그램(https://github.com/lis123kr/GPA)의 input 파일 로 사용하여 분석하였다. 이 프로그램은 서열간의 소수염기비율을 비교하고, 유전적다형성을 찾아 다양한 형태로 분석한 결과를 보 여준다.

\section{결과}

\section{백신주 간의 SNP 분석}

수두 백신주 간의 대표 염기서열이 다른 SNP 분석을 통해 어떠한 분자유전학적 차이가 있는지 알아보고자 하였다. VZV의 게놈 구조상 terminal repeat long (TRL)과 internal repeat long (IRL), internal repeat short (IRS)와 terminal repeat short (TRS)는 각각 역상 보적인 관계로, 중복으로 분석되는 것을 피하고자 TRL과 TRS를 제외하고 분석하였다. TRL과 TRS를 제외한 부위에서 세 백신주 사이에 염기가 서로 다른 SNP는 모두 38 개로 분석되었다 (Table 1). Open reading frame (ORF)에서 29 개, non-coding region (NCR)에서 9 개로 나타났다. 치환으로 인한 SNP는 모두 29 개이었으며, transition (22개)이 transversion (7개) 보다 많이 발생하였다. ORF 지역 에서의 염기 치환으로 인해 아미노산이 변하지 않는 동의적 변이는 8개로 모두 transition으로 인해 발생하였고, 아미노산 서열이 변하는 비동의적 변이는 모두 17 개로 10 개의 transition과 7 개의 transversion으로 인하였다. NCR에서의 치환 4 곳은 모두 transition이었 다. 특이하게도 transversion 7 군데는 R1 지역에서 2 군데, R2 지역에서 4 군데, 그리고 R3지역에서 1 군데 등, 모두 R지역에서 관찰되 었다(Data not shown).

삽입/결실은 ORF에서 4 군데, NCR에서 5 군데 관찰되었다. ORF에서의 삽입/결실은 ORF11의 R1에서 3 군데와 ORF22의 R3에서 한 군데에서 관찰되었다. NCR의 삽입/결실 중 두 개는 NCR62/63의 R4와 ORI 지역에서 관찰되었다. R지역에서의 삽입/결실에는 여러 개 의 뉴클레오티드가 관여하였으며, 그 숫자는 R1에서 세 군데에서 15 개씩, R3에서 27 개, 그리고 R4에서 54 개였다. 이들 숫자는 무작 위적인 것이 아니라 각 $\mathrm{R}$ 지역에서의 반복 단위 길이와 일치하기 때문에 실제로 이 $\mathrm{R}$ 지역에서의 삽입/결실이 반복 단위로 이루어졌는지

Table 1. Mutational events identified at SNP sites among the VZV vaccine strains

\begin{tabular}{|c|c|c|c|c|c|c|}
\hline & \multicolumn{4}{|c|}{ Substitution } & \multirow{2}{*}{ In/del } & \multirow{2}{*}{ Total } \\
\hline & & $\mathrm{TS}^{\mathrm{a}}$ & $\mathrm{TV}^{\mathrm{b}}$ & Subtotal & & \\
\hline \multirow[t]{3}{*}{ ORF } & Synonymous & 8 & - & 8 & - & 8 \\
\hline & Non-synonymous & 10 & 7 & 17 & - & 17 \\
\hline & Subtotal & 18 & 7 & 25 & 4 & 29 \\
\hline \multirow[t]{2}{*}{$N C R$} & & 4 & - & 4 & 5 & 9 \\
\hline & Total & 22 & 7 & 29 & 9 & 38 \\
\hline
\end{tabular}

atransition

${ }^{b}$ transversion 
(A) Consensus nucleotide sequence of the repeating units of the $R$ sequences

\begin{tabular}{|c|c|}
\hline R1 & $\begin{array}{l}\text { A(18bp) : GGACGCGATCGACGACGA } \\
\text { B (15 bp) : GGRMGMGGCGGAGGA }\end{array}$ \\
\hline R2 & $\begin{array}{l}\text { A(42 bp) : GCGGATCGGGCTTTCGGGAAGCCGGCCGAGGTGGGCGCGACG } \\
\text { B (32 bp) : GCGGGATCGGGCTTTCGGGTAGCGGCCGAGGT }\end{array}$ \\
\hline R3 & A( 9 bp) : GMCCGYSCA \\
\hline R4 & $\begin{array}{l}\text { A(27 bp) : CCCCGCCGATGGGGAGGGGGCGCGGTA } \\
\text { B (11 bp) : CCCCGCCGATG }\end{array}$ \\
\hline
\end{tabular}

R: $A$ or $G, M: A$ or $C, Y: C$ or $T, S: C$ or $G$

(B) Number of the repeating units of the $R$ sequences

\begin{tabular}{|c|c|c|c|}
\hline \multirow{3}{*}{$\mathrm{R} 1$} & Suduvax: $A B B A B B A B B-A B B A B B A B$ & \multirow{3}{*}{ R2 } & Suduvax: AAAAAAAB \\
\hline & $\therefore$ ABBABBABBBAB-AB-AB & & Varilrix : AAAAAAAB \\
\hline & Varivax : ABBABBABBBAB-AB-AB & & Varivax : AAAAAAAB \\
\hline \multirow{3}{*}{ R3 } & Suduvax: AAAAAAAAAA & \multirow{3}{*}{ R4 } & Suduvax: --AAAB \\
\hline & AAAAAAA--- & & Varilrix : $A A A A A B$ \\
\hline & AAAAAAA--- & & Varivax : AAAAAB \\
\hline
\end{tabular}

Fig. 1. Consensus nucleotide sequence and the number of the repeating units of the R sequences.

알아 보았다. Fig. 1에 나타낸 바와 같이 R1에서는 $15 \mathrm{bp}$ 로 구성된 B반복단위가, R3에서는 $9 \mathrm{bp}$ 로 구성된 A반복단위 3 개가, 그리고 $\mathrm{R} 4$ 에는 $27 \mathrm{bp}$ 로 구성된 A반복단위 2 개가 삽입/결실에 관여한 것을 알 수 있다.

SNP 중 세 백신주 모두 다른 경우는 없었다. 치환에 의한 29 개의 SNP에서 Suduvax만 다른 경우는 10 군데, Varilrix만 다른 경우는 6 군데, 그리고 Varivax만 다른 경우는 13 군데로 Varivax의 염기서열이 다름으로써 생성된 SNP가 가장 많았다. R지역에서의 삽입/결실에 의한 SNP의 경우 Suduvax에서만 다르고, Varilrix와 Varivax에서는 동일하게 관찰되었다.

\section{백신주의 유전적 다형성 분석}

소수 염기의 비율이 $5 \%$ 이상인 부위를 GPS라 한다. Suduvax에서 89 개, Varilrix에서 68 개, Varivax에서 116 개로, GPS의 수는 Varivax에서 가장 많았고, Varilrix에서 가장 적었다(Table 2). 그러나 GPS에서의 소수 대립유전자형 빈도(Minor allele frequency, MAF)의 평균은 Varilrix에서 제일 높았고, Varivax에서 제일 낮았다. GPS는 VZV 백신주 게놈 전체에 골고루 분포하지 않고 특정 부위에 비교적 많이 관찰되는 것을 알 수 있다(Fig. 2). GPS가 상대적으로 많이 관찰되는 ORF는 ORF11, 14, 22, 31, 55, 그리고 62이다. 이 중 ORF11, 14, 22 지역은 각각 R1, R2, R3 지역을 포함하므로 이들 ORF에서의 GPS 형성에 R 지역의 역할을 알아보고자 하였다. Table 2

Table 2. The number of GPS and mean MAF at GPS found in the three VZV vaccine strains

\begin{tabular}{|c|c|c|c|c|c|c|c|c|c|}
\hline & \multicolumn{3}{|c|}{ Suduvax } & \multicolumn{3}{|c|}{ Varilrix } & \multicolumn{3}{|c|}{ Varivax } \\
\hline & Length(bp) & No. GPS & Avg. MAF & Length(bp) & No. GPS & Avg. MAF & Length(bp) & No. GPS & Avg. MAF \\
\hline Genome & 117397 & 89 & 20.1 & 117407 & 68 & 23.0 & 117402 & 116 & 16.9 \\
\hline ORF & 106047 & 80 & 20.2 & 106005 & 61 & 22.9 & 106005 & 103 & 17.5 \\
\hline NCR & 11350 & 9 & 19.2 & 11402 & 7 & 23.5 & 11397 & 13 & 12.0 \\
\hline ORF11 & 2430 & 15 & 19.7 & 2415 & 2 & 8.6 & 2415 & 2 & 16.0 \\
\hline R1 & 276 & 15 & 19.7 & 261 & 2 & 8.6 & 261 & 2 & 16.0 \\
\hline ORF14 & 1683 & 9 & 24.6 & 1683 & 10 & 27.3 & 1683 & 16 & 19.4 \\
\hline $\mathrm{R} 2$ & 326 & 8 & 21.5 & 326 & 9 & 26.8 & 326 & 15 & 19.6 \\
\hline ORF22 & 8319 & 19 & 16.2 & 8292 & 15 & 20.4 & 8292 & 13 & 17.5 \\
\hline R3 & 93 & 13 & 15.9 & 66 & 10 & 19.4 & 66 & 10 & 16.8 \\
\hline
\end{tabular}


(A)

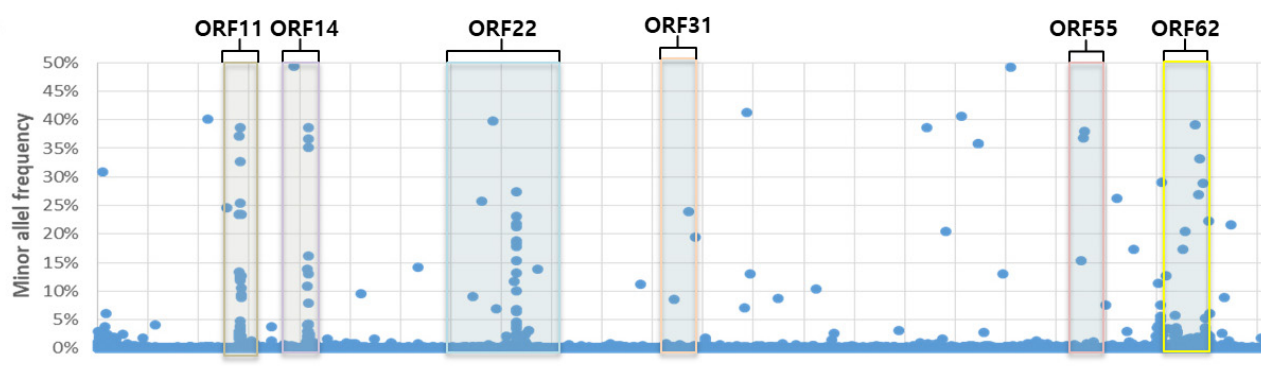

(B)

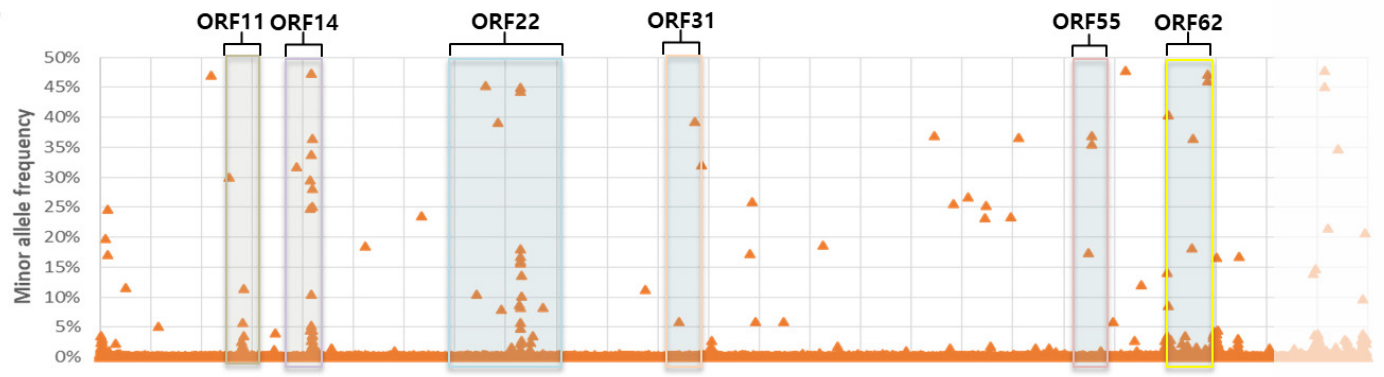

(C)

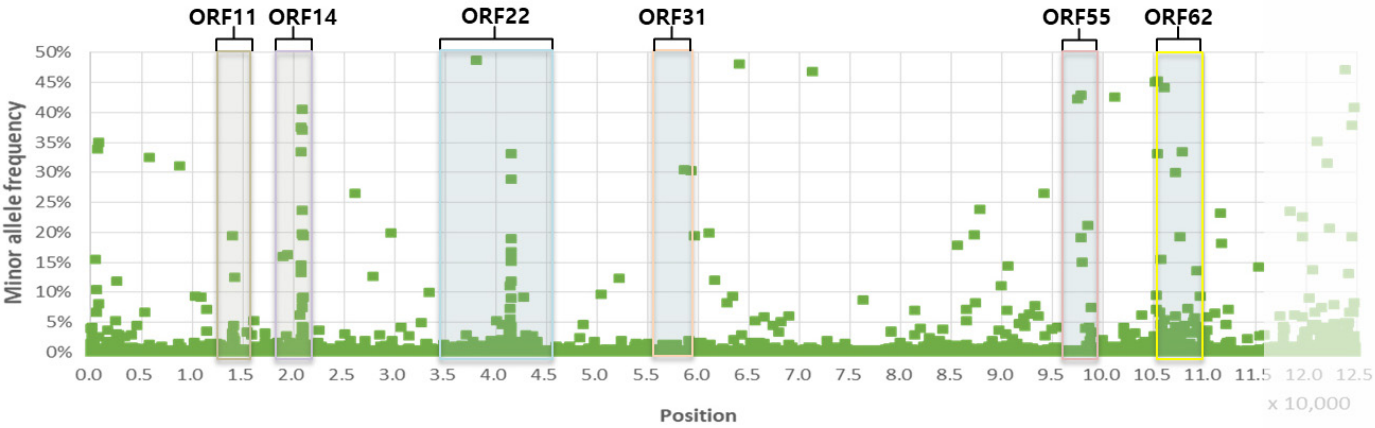

$\mathrm{TR}_{\mathrm{L}}$

$U_{L}$

$\begin{array}{llll}\mathbf{I R}_{\mathbf{L}} & \mathbf{I R}_{\mathbf{S}} \quad \mathbf{U}_{\mathrm{S}} \quad \mathrm{TR}_{\mathrm{S}}\end{array}$

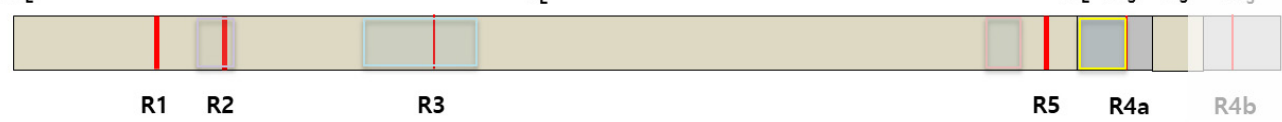

Fig. 2. Distribution of GPS on the genome of VZV vaccine strains. Nucleotide positions are shown in $X$ axis, and the frequency of minor alleles at GPS is shown in $Y$ axis. Genome structure of VZV is shown at the bottom of the Figure. (A), Suduvax; (B), Varilrix; (C), Varivax.

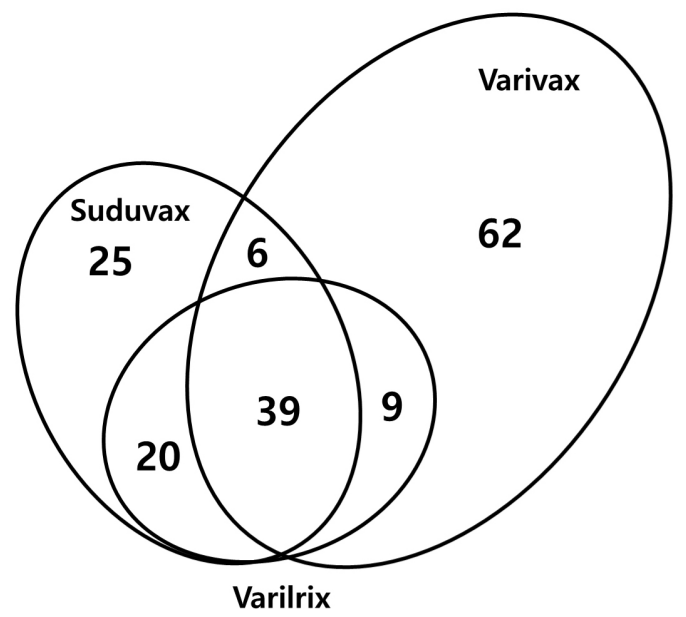

Fig. 3. The number of GPS shared among the three VZV vaccine strains. 
에서 볼 수 있는 바와 같이 세 백신주 모두에서 ORF11, 14, 22의 GPS는 대부분 이들 ORF에 포함되어 있는 R1, R2, R3에 기인한 것임 을 알 수 있었다. 특히 세 백신주 모두에서 ORF11의 GPS는 $100 \%$ R1에 의한 것이며, ORF14의 GPS는 각 백신주에서 하나를 제외한 나머지가 R2에 기인한 것임을 알 수 있다. 특이하게도 ORF14의 GPS 중 R2에 속하지 않는 하나의 GPS는 세 백신주 모두에서 같은 위치 였다(Dumas 기준 19431 위치). ORF14/R2나 ORF22/R3에서 세 백신주 사이에 GPS의 개수나 평균 MAF 값에서 큰 차이는 없는 것으 로 보인다(Table 2). 그러나 ORF11/R1의 경우, Oka-유래 두 백신주에 비해 Suduvax에서 횔씬 많은 15 개의 GPS가 관찰되었다. Varilrix와 Varivax에서는 각각 2 개의 GPS가 관찰되었으며, 이 두 GPS의 게놈상 위치는 동일하였다. ORF31과 55에서는 모든 백신주 에서 3 개 이상의 GPS가 관찰되었으며, R 지역을 포함하는 ORF를 제외하면 ORF62에서 가장 많은 GPS가 관찰되었다(Fig. 2). 세 백신 주의 ORF별 GPS의 수와 평균 MAF 값은 Supplemented Table 1에 나타나 있다.

세 백신주간의 GPS 분포를 살펴 보았다. 세 백신주 중 어느 하나에서라도 관찰되는 GPS의 수는 모두 161 개였다(Supplemented Table 2). 이 중 세 백신주 모두에서 관찰되는 GPS는 39 개였고, 두 백신주에서는 공통으로 관찰되지만 세번째 백신주에서는 관찰되지 않는 GPS의 수는 Fig. 3에 나타낸 바와 같다. 또한 Suduvax에서만 관찰되는 GPS는 25 개, Varivax에서만 관찰되는 GPS는 62 개인 반면, Varilrix에서만 관찰되는 GPS는 없는 것으로 나타났다(Fig. 3). 이 중 세 백신주에서 공통으로 나타나는 GPS 39 개에 대해서 좀 더 자세 히 살펴 보았다. 세 백신주 모두에서 적어도 하나 이상의 GPS가 관찰되는 ORF는 모두 20 개인데(Supplemented Table 2), 이 중 16개의 ORF와 하나의 NCR에서 세 백신주 공통인 GPS가 관찰되었다. 특히 ORF22에서 9개, ORF14에서 8개로 많은 공통 GPS가 관찰되었다. 공통 GPS에서의 평균 MAF는 세 백신주에서 $23.1 \%$ (Suduvax) 26.5\% (Varilrix)로 전체 GPS의 평균 MAF보다 높았다. 세 백신주 공통인 39 개 GPS 중 17 개가 SNP에도 해당되었다.

\section{고찰}

현재 수두를 예방하기 위해서 전 세계적으로 사용되는 백신은 모두 약독화 생백신이다. 수두백신은 여러 계대배양을 거쳐 약독화 되었으 며 $(5,8)$, 약독화 과정에 대한 명확한 메커니즘은 아직 확인되지 않은 상태이다. VZV는 서열 간의 변이가 적어 유전학적 보존성이 크기 때문에, 변이의 분석이 용이하다. 조금씩 발생하는 변이들은 선택압에 의해 축적되어 유전적 다양성이 증가하게 된다. 본 연구에서는 NGS 기법을 사용하여 대표적인 수두 백신주들을 SNP 분석과 유전적 다형성 분석을 통해 약독화에 따른 각 백신주가 어떠한 유전적 특징 과 다양성을 가지는지 분석하고자 하였다.

세 백신주에서 공통적으로 SNP와 GPS가 많이 관찰되어 유전적으로 다양성이 높은 지역은 ORF 11, 14, 그리고 22로 나타났다. ORF11 은 RNA에 결합하는 단백질을 만들며, glycoprotein E와 IE62 단백질의 발현에 어느 정도 기여하기 때문에, in vivo상에서 병원성에 영향 을 미치게 된다 (18). ORF14는 glycoprotein C를 만들며, 이 단백질은 숙주세포 안으로 바이러스가 진입하는데 필요한 transmembrane protein을 만든다. 이 유전자는 바이러스 증식에 꼭 필요한 유전자는 아니지만, 계대가 진행된 바이러스 주에서는 야생형 바이러스 보다 glycoprotein C의 발현율이 낮다고 알려져 있다 $(19,20)$. ORF22는 바이러스 증식에 필수적인 유전자로 허피스바이러스에 잘 보존되 어 있으며, VZV 단백질 중 가장 큰 inner tegument protein을 암호화한다. 이 단백질은 숙주세포 내의 CRLs (Cullin-RING ubiquitin ligases)을 분해시켜 숙주세포의 S기 진입을 막아 바이러스의 증식이 효과적으로 이루어지게 만든다 (21). 이들 유전자의 SNP와 GPS에 의한 유전적 다양성은 백신주들의 약독화와 어느 정도 관계가 있는 것으로 생각되지만, 아직 직접적인 연관성에 관한 연구 결과는 없으므 로 향후 연구가 필요한 부분이라고 본다.

ORF $11,14,22$ 의 유전적 다양성은 대부분이 각 ORF에 존재하는 반복 서열인 R 지역(R1, R2, R3)에 의해 나타나고 있다. R 지역은 특 정한 길이를 가지는 서열들이 반복되어 있고, 그 반복 개수는 VZV주에 따라 다양하다 (22). R1은 여러 개의 $18 \mathrm{bp}$ 단위와 $15 \mathrm{bp}$ 단위의 조합에 의해 이루어져 있다. Suduvax는 Oka-유래 백신주들에 비해 $15 \mathrm{bp}$ 단위 하나를 더 가지고 있다. R2는 $42 \mathrm{bp}$ 단위 여러 개와 42 $\mathrm{bp}$ 의 일부분인 $32 \mathrm{bp}$ 단위 하나로 구성되어 있다. R3는 ORF22의 3' 말단에 존재하며, 여러 개의 $9 \mathrm{bp}$ 단위로 구성되어 있다.

NCR 중에서는 ORF 62와 63 사이에 위치하는 NCR62/63이 유전적으로 가장 다양한 것으로 나타났다. NCR62/63에는 반복 서열인 R4 지역과 ORI 지역이 있다. R4 지역은 여러 개의 $27 \mathrm{bp}$ 단위와 그 일부분이 $11 \mathrm{bp}$ 단위로 구성되어 있다. Suduvax는 Oka-유래 백신주들 에 비해 $54 \mathrm{bp}$ 의 결실이 있는데 이는 $27 \mathrm{bp}$ 단위 두 개가 결실된 것이다. ORI 지역은 DNA 복제가 시작되는 지역으로, TA 서열이 여러 개 반복되어 있다. ORI 지역의 TA 반복 횟수를 임상주인 pOka와 비교해 보았을 때, vOka 유래 백신주(Varilrix, Varivax)에서 더 적게 나 타났다. 이러한 TA 반복 지역이 짧으면 게놈 복제 효율이 낮아진다는 연구 결과를 감안하면 (23), ORI 지역에서의 염기 TA의 반복성이 백신주간 달라 vOka 유래 백신주의 게놈 복제 효율이 낮을 것으로 추측한다. 
$\mathrm{R}$ 지역을 포함하는 ORF의 유전적 다양성이 높은 것은 앞에서 설명한 바 있다. 이들 ORF11, 14, 22 이외에도 ORF31, ORF55와 ORF62 지역에서 비교적 높은 유전적 다양성이 관찰되었다. ORF31은 VZV가 증식하기 위한 필수적인 유전자로, glycoprotein B를 암호화한다. Glycoprotein B는 virion envelope 표면에 형성되며, 숙주 세포의 receptor와 결합하여 세포 내로 진입을 위해 세포막과 융합에 관여한 다 $(24,25)$. ORF55는 VZV가 증식하기 위한 필수적인 유전자로 알려져 있다. Helicase/primase 복합체를 만들며, replication fork에 서 DNA를 풀어 단일 가닥 DNA를 만들고, leading strand와 lagging strand에서 DNA 합성이 일어나게 한다. ORF62는 VZV가 증식하 기 위한 필수적인 유전자로 알려져 있으며, 초기 유전자의 trans-activating factor에 관여한다. ORF62 지역은 많은 돌연변이가 발생하 며, 바이러스의 증식을 억제시켜 VZV의 약독화에 가장 중요한 $\mathrm{ORF}$ 로 알려져 있다 $(3,11,26)$

세 백신주 간의 SNP 중 동의적 치환이 일어난 8 군데는 해당 유전자의 기능에 영향을 주지 않을 것으로 생각된다. 비동의적 치환 17 군데 중에서 9 군데는 같은 그룹의 아미노산으로 바뀌기 때문에 단백질의 구조와 기능에는 큰 영향을 미치지 않을 것으로 생각된다. 그러나 나머 지 8 군데에서는 다른 그룹의 아미노산으로 치환되므로 단백질의 구조와 기능에 영향을 줄 것으로 생각된다. 예를 들어 Asn/Lys 치환이 모 두 세 군데(Dumas 위치 20745, 20787, 20871)에서 관찰되었는데, 이 세 군데는 모두 ORF14에 존재하므로 세 백신주 간의 유전적 다양 성에 크게 관여할 것으로 생각된다. ORF55에서는 Ala/Thr과 Arg/Cys의 두 치환이 관찰되었으며, ORF59에서 Arg/GIn 치환이, ORF62에 서 Met/Thr 치환이, 그리고 ORF64에서는 Arg/GIn 치환이 관찰되었다. 이와 같은 다른 그룹 아미노산으로의 치환이 백신주에 어떤 영향을 미칠지에 대해서는 아직 알려진 바가 없으나, 세 백신주의 효율성과 돌파감염의 차이에 어느정도 기여할 것으로 생각된다 $(10,11,27)$.

\section{ACKNOWLEDGMENTS}

본 연구는 부분적으로 (주)G녹십자의 연구비 지원으로 수행되었으며 이에 감사를 드립니다.

\section{REFERENCES}

1) Quinlivan M, Breuer J. Molecular studies of Varicella zoster virus. Rev Med Viro/2006;16:225-50.

2) Gershon AA, Gershon MD. Pathogenesis and current approaches to control of varicella-zoster virus infections. Clin Microbiol Rev 2013;26:728-43.

3) Zerboni L, Sen N, Oliver SL, Arvin AM. Molecular mechanisms of varicella zoster virus pathogenesis. Nat Rev Microbiol 2014;12:197-210

4) Gilden DH, Kleinschmidt-DeMasters BK, Laguardia JJ, Mahalingam R, Cohrs RJ. Neurologic complications of the reactivation of varicella-zoster virus. N Eng/ J Med 2000;342:635-45.

5) Takahashi M, Otsuka T, Okuno Y, Asano Y, Yazaki T. Live vaccine used to prevent the spread of varicella in children in hospital. Lancet 1974;2:1288-90.

6) D'Hondt E, Berge E, Colinet G, Duchene M, Peetermans J. Production and quality control of the Oka-strain live varicella vaccine. Postgrad Med J 1985;61:53-6.

7) Kuter BJ, Weibel RE, Guess HA, Matthews H, Morton DH, Neff BJ, et al. Oka/Merck varicella vaccine in healthy children: final report of a 2-year efficacy study and 7-year follow-up studies. Vaccine 1991;9:643-7.

8) Sohn YM, Park CY, Hwang KK, Woo GJ, Park SY. Safety and immunogenicity of live attenuated varicella virus vaccine (MAV/06 strain). J Korean Ped 1994;37:1405-13.

9) Gomi Y, Sunamachi H, Mori Y, Nagaike K, Takahashi M, Yamanishi K. Comparison of the complete DNA sequences of the Oka varicella vaccine and its parental virus. J Viro/2002;76:11447-59.

10) Tillieux SL, Halsey WS, Thomas ES, Voycik JJ, Sathe GM, Vassilev V. Complete DNA sequences of two oka strain varicella-zoster virus genomes. J Viro/2008;82:11023-44. 
11) Jeon JS, Won YH, Kim IK, Ahn JH, Shin OS, Kim JH, et al. Analysis of single nucleotide polymorphism among varicella-zoster virus and identification of vaccine-specific sites. Virology 2016:496:277-86.

12) Domingo E, Sheldon J, Perales C. Viral quasispecies evolution. Microbio/ Mol Biol Rev 2012;76:159-216.

13) Eigen M, Schuster P. The Hypercycle. A principle of natural self-organization. Naturwissenschaften 1977;64:541-65.

14) Sauder CJ, Vandenburgh KM, Iskow RC, Malik T, Carbone KM, Rubin SA. Changes in mumps virus neurovirulence phenotype associated with quasispecies heterogeneity. Virology 2006:350:48-57.

15) Cricca M, Morselli-Labate AM, Venturoli S, Ambretti S, Gentilomi GA, Gallinella G, et al. Viral DNA load, physical status and E2/E6 ratio as markers to grade HPV16 positive women for high-grade cervical lesions. Gynecol Oncol 2007;106:549-57.

16) Schmutzhard J, Riedel HM, Wirgart BZ, Grillner L. Detection of herpes simplex virus type 1, herpes simplex virus type 2 and varicella-zoster virus in skin lesions. Comparison of real-time PCR, nested PCR and virus isolation. J Clin Virol 2004;29:120-6.

17) Hedrick P. Genetics of populations. Jones \& Bartlett Learning, 2011.

18) Che $X$, Oliver SL, Sommer MH, Rajamani J, Reichelt M, Arvin AM. Identification and functional characterization of the Varicella zoster virus ORF11 gene product. Virology 2011:412:156-66.

19) Cohen Jl, Seidel KE. Absence of varicella-zoster virus (VZV) glycoprotein $V$ does not alter growth of VZV in vitro or sensitivity to heparin. J Gen Viro/ 1994;75:3087-93.

20) González-Motos V, Jürgens C, Ritter B, Kropp KA, Durán V, Larsen O, et al. Varicella zoster virus glycoprotein C increases chemokine-mediated leukocyte migration. PLoS Pathog 2017;13:e1006346.

21) Kwon KM, Ahn JH. Herpesvirus-encoded deubiquitinating proteases and their roles in regulating immune signaling pathways. J Bacteriol Virol2013;43:244-52.

22) Tyler SD, Peters GA, Grose C, Severini A, Gray MJ, Upton C, et al. Genomic cartography of varicella-zoster virus: a complete genome-based analysis of strain variability with implications for attenuation and phenotypic differences. Virology 2007:359:447-58.

23) Khalil MI, Arvin A, Jones J, Ruyechan WT. A sequence within the varicella-zoster virus (VZV) OriS is a negative regulator of DNA replication and is bound by a protein complex containing the VZV ORF29 protein. $J$ Virol 2011:85:12188-200.

24) Oliver SL, Brady JJ, Sommer MH, Reichelt M, Sung P, Blau HM, et al. An immunoreceptor tyrosine-based inhibition motif in varicella-zoster virus glycoprotein B regulates cell fusion and skin pathogenesis. Proc Natl Acad Sci U S A 2013:110:1911-6.

25) Yang E, Arvin AM, Oliver SL. The glycoprotein B cytoplasmic domain lysine cluster is critical for varicella-zoster virus cell-cell fusion regulation and infection. J Viro/2016:91:e01707-16.

26) Depledge DP, Kundu S, Jensen NJ, Gray ER, Jones M, Steinberg S, et al. Deep sequencing of viral genomes provides insight into the evolution and pathogenesis of varicella zoster virus and its vaccine in humans. Mol Biol Evol 2014;31:397-409.

27) Quinlivan M, Breuer J. Clinical and molecular aspects of the live attenuated Oka varicella vaccine. Rev Med Virol 2014:24:254-73. 